PAEDAGOGIA ChristianA

2/24 (2009) - ISSN 1505-6872

Stanisław Zarzycki*

Lublin

\title{
Człowiek jako podmiot w ujęciu teologicznym
}

Ogólnie przez podmiot rozumiemy „to, w czym coś tkwi lub jest zawarte, czemu coś przysługuje” albo kogoś jako „sprawcę zarówno aktów wewnętrznych (poznawczych, wolitywnych i emocjonalnych)"', jak i tych zewnętrznych, czyli czynów zmieniających otaczająca go rzeczywistość.

Pytanie o podmiotowość człowieka jest nie tylko zagadnieniem teoretycznym, ale także egzystencjalną kwestią naszych czasów, co świadczy i o jego ważności i aktualności. Dla jej zobrazowania niech posłużą wypowiedzi ostatnich papieży. Zastanawiając się nad przyczyną lęku współczesnego człowieka i upatrując ją w jego własnych wytworach, Jan Paweł II w swej pierwszej encyklice Redemptor hominis pytał:

Czy wszystkie dotychczasowe i dalsze osiagnięcia techniki idą w parze z postępem etyki i duchowym postępem człowieka? Czy człowiek jako człowiek w ich kontekście również rozwija się i postępuje naprzód, czy też cofa się i degraduje w swoim człowieczeństwie? Czy rośnie w ludziach, w «świecie człowieka», który jest sam w sobie światem dobra i zła moralnego, przewaga tego pierwszego, czy tego drugiego? Czy w ludziach, pomiędzy ludźmi, pomiędzy społeczeństwami, narodami, państwami, rośnie sprawiedliwość, solidarność, miłość społeczna, poszanowanie praw każdego - zarówno człowieka, jak i narodu czy ludu - czy też, wręcz przeciwnie, narastają egoizmy różnego wymiaru, ciasne nacjonalizmy w miejsce autentycznej miłości ojczyzny, a wreszcie dążenie do panowania nad drugimi wbrew ich słusznym prawom i zasługom, dążenie zwłaszcza do tego, aby cały rozwój materialny, techniczno-produkcyjny, wykorzystać dla celów wyłącznego panowania nad drugi$\mathrm{mi}$, dla celów takiego czy innego imperializmu? (RH 15)

* Dr hab. Stanisław T. Zarzycki SAC, kierownik Katedry Antropologii Duchowej w Instytucie Teologii Duchowości Wydziału Teologii KUL.

${ }^{1}$ J. Herbut, Podmiot, w: tenże (red.), Leksykon filozofii klasycznej, Lublin 1997, s. 425. 
Trzydzieści lat później, papież Benedykt XVI w encyklice Caritas in veritate. O integralnym rozwoju ludzkim w mitości i prawdzie odnosi się do tych pytań, podzielając obawy swego Poprzednika o ambiwalencji rozwoju w świecie współczesnym:

Ryzyko naszych czasów - pisze Papież - polega na tym, że faktycznej wzajemnej zależności między ludźmi i narodami nie odpowiada etyczne współdziałanie sumień i umysłów, którego wynikiem mógłby być rozwój naprawdę ludzki. Jedynie dzięki miłości, oświeconej światłem rozumu i wiary, możliwe jest osiągnięcie celów rozwoju bardziej ludzkich i humanizujących. Dzielenia się dobrami i zasobami, będącymi źródłem autentycznego rozwoju, nie zapewnia jedynie postęp techniczny i czysto interesowne relacje, lecz potencjał miłości zwyciężający zło dobrem (por. Rz 12, 21) i otwierający na wzajemność sumień i wolności (CV 9).

Obecny Papież stwierdza tu wyraźnie, że „osiagnięcie celów bardziej ludzkich i humanizujących", a więc tych, które chronią i jednocześnie promują podmiotowość człowieka i ludzkości, jest dzisiaj możliwe ,jedynie dzięki miłości oświeconej światłem rozumu i wiary", i dodaje, że nie uwzględniając tych źródeł sensu ,człowiek skazuje się na empiryczną i sceptyczną wizję życia, niezdolną wznieść się ponad praxis, ponieważ nie interesuje jej dostrzeżenie wartości a czasem nawet znaczeń - dzięki którym mogłaby ją osądzać i ukierunkować" (CV 9).

Skoro prawda odczytywana w świetle rozumu i wiary oraz miłość objawiona w Chrystusie są gwarantem zachowania podmiotowości człowieka, jak również narodów i ludów, i jej promocji w świecie dzisiaj, niezwykłego znaczenia i, chciałoby się powiedzieć, aktualności, nabiera teologiczny wymiar podmiotowości człowieka. Pełniejsze ukazanie jego istoty domaga się uwzględnienia objawienia, Magisterium Kościoła i nauki wielu teologów, tu jednak ograniczymy się do najbardziej istotnych myśli na ten temat.

Warto zauważyć, że pojęcie podmiotowości jest pojęciem wieloznacznym. Jest ono związane z człowiekiem, z jego osobowym ,ja”, a nawet jest czymś od niego oddzielonym i funkcjonującym w jego świecie duchowym. Mówi się o podmiocie gramatycznym, estetycznym, psychologicznym, moralnym, prawnym, filozoficznym i religijnym.

W sensie gramatycznym i logicznym podmiot to część zdania niezależna od innych składników. Jeśli jest nią rzeczownik (osoba lub przedmiot), o którym się mówi w orzeczeniu, że wykonuje jakąś czynność, i stawia się go w mianowniku, zwany jest on podmiotem gramatycznym, jeśli natomiast występuje on w innym przypadku, określa się go podmiotem logicznym ${ }^{2}$. W znaczeniu estetycznym podmiotem jest ktoś, komu udzielone zostaje przeżycie przedmiotu (elementu natury, drugiej osoby, dzieła sztuki), któremu chce się on przypatrzeć, gdyż tenże

${ }^{2}$ P. Bąk, Gramatyka języka polskiego, Warszawa 1987, s. 409. 
przedmiot go intryguje, zachwyca i uszczęśliwia ${ }^{3}$. W znaczeniu psychologicznym o podmiocie mówimy wtedy, gdy mamy na myśli ludzkie ,ja” cechujące się pewną stałością i tożsamością aktów psychicznych, przeżyć psychicznych, bezpośrednio sobie uświadamianych. Pozostaje ono stałą, niezmienną zasadą tychże zmiennych doświadczeń ${ }^{4}$. W znaczeniu moralnym podmiotem jest człowiek uświadamiający sobie „to, co powinien czynić” i ,dlaczego powinien to czynić”, wybrać tę oto wartość moralną, wypełnić jakiś obowiązek ${ }^{5}$, np. pomóc człowiekowi choremu. Odczytana a następnie urzeczywistniona powinność jest, jak wiadomo, czymś konstytutywnym dla moralności. W znaczeniu prawnym pojęcia podmiotu używa się na oznaczenie osoby fizycznej lub prawnej mogącej posiadać określone prawa i obowiązki. W znaczeniu filozoficznym, tak jak to jest objaśniane w filozofii realistycznej, za podmiot uznaje się ludzkie ,ja” zdolne do podmiotowania wszystkich czynności (materialnych - spełnianych przez organy cielesne, oraz duchowych - intelektualnego poznania i decyzji woli), które ono uznaje za „swoje”, do niego przynależne, bo są one ku niemu skierowane. „Ja” jest ich centrum, spełniaczem, a więc podmiotem ${ }^{6}$. Wreszcie w znaczeniu religijnym podmiot to człowiek, który nawiązuje relację z transcendencją, rzeczywistością sakralną (nazywaną „tajemnicą”, „bóstwem”, „czymś wyższym”, „Bogiem”), uznaje jej realną obecność i udziela jej odpowiedzi na jej wezwanie, słowo, miłość z pełnym zaangażowaniem swych władz poznawczych i wolitywno-emocjonalnych ${ }^{7}$, mając nadzieję na osiagnięcie ostatecznego swego celu, szczytu swej bytowości. W tym ujęciu podmiot spełnia się przede wszystkim w relacji wertykalnej, równie zgodnej z jego natura, jak jego relacja horyzontalna do innych osób i rzeczy.

W chrześcijaństwie podmiotem jest człowiek wiary w Boga objawionego w Jezusie Chrystusie w mocy Ducha Świętego. Wchodzi on w relację z Trójosobowym Bogiem, przyjmując wiarą Jego słowo, wezwanie, miłość w Kościele Chrystusowym i stara się na nie odpowiedzieć wypełniając Boże przykazania, zwłaszcza przykazanie miłości Boga i bliźniego. Z racji Wcielenia Syna Bożego relacja chrześcijanina do Boskiego „Ty” jest ściślej powiązana, niż w innych religiach, z relacją do innych osób, co nie pozostaje bez znaczenia dla rozumienia i urzeczywistniania się podmiotowości człowieka w tejże religii Wcielenia.

3 A. B. Stępień, Propedeutyka estetyki, Warszawa 1975, s. 122.

${ }^{4}$ V. Marcozzi, Antropologia psicologica, Roma 1978, s. 281-282.

${ }^{5}$ K. Wojtyła, Człowiek w polu odpowiedzialności, Rzym-Lublin 1991, s. 28.

${ }^{6}$ M. A. Krąpiec, Ja-człowiek. Zarys antropologii filozoficznej, Lublin 1974, s. 107-108. Od owego ,ja”, zdolnego do podmiotowania swych aktów, wspomniany autor odróżnia ,ja” fenomenologiczne z ośrodkiem dyspozycyjnym (centrum psychicznym) w relacji do rzeczy zewnętrznych. To ,ja” rozwija się i ,więdnie” wraz z rozwojem psychicznym i starzeniem się człowieka. Tamże, s. $103-104$.

${ }^{7}$ Z. Zdybicka, Człowiek i religia. Zarys filozofii religii, Lublin 1993, s. 270-273. 


\section{Teologiczne podstawy podmiotowości czlowieka}

Wydaje się, że w objaśnieniu podmiotowości człowieka według najnowszego nauczania Kościoła i teologii posoborowej najlepiej jest wyjść od teologii stworzenia i uwzględnić perspektywę historiozbawczą, w tym zwłaszcza chrystologiczna. Taka optyka pozwoli na pokazanie pewnej dynamiki wpisanej w ludzką podmiotowość, pewnej potencjalności i stwarza lepsze możliwości dla rozpatrzenia pewnych kwestii związanych zwłaszcza ze spełnieniem się człowieka jako podmiotu.

Taką perspektywę na ten temat przyjął w swym nauczaniu Sobór Watykański II, który z dotychczasowych Soborów najbardziej zajął się problematyką człowieka i nawet wypracował pewien zarys antropologii, nie kompletnej, nie integralnej, lecz takiej, która uwzględnia pewne punkty widzenia siebie, swych osiagnnięć i wielkości oraz swych porażek i swej nędzy, przez człowieka współczesnego. Owa antropologia znajdzie swe teoretyczne rozwinięcie u wielu teologów posoborowych, a także papieża Jana Pawła II.

Podstawą całej antropologii chrześcijańskiej, według Soboru, a zwłaszcza Konstytucji o Kościele w świecie współczesnym, jest nauka o obrazie Bożym. Przybliżenie jej pozwoli dostrzec najpierw w człowieku podmiot, sprawcę aktów wewnętrznych (poznawczych, wolitywnych i emocjonalnych) oraz zewnętrznych, czynów zdolnych przeobrażać świat, a następnie uświadomić sobie jego sytuację dzisiaj i możliwości spełnienia się. Wychodząc od słów Księgi Rodzaju: „A wreszcie rzekł Bóg: «Uczyńmy człowieka na Nasz obraz, podobnego nam»" $(1,26)$, Ojcowie Soborowi ukazują wielką godność człowieka i jego powołanie. Wyodrębniają pewne elementy tego obrazu, które uwydatniają wyjątkowość człowieka pośród innych stworzeń i jego podmiotowość.

Wypowiadając się na temat natury człowieka, ujmująją w jej ,jedności ciała i duszy" (KDK 14). Ciało jest współczynnikiem bytu ludzkiego, współtworzy go i bierze udział w odniesieniu człowieka do Boga. Decydującym czynnikiem składowym człowieka jest jednak ,dusza duchowa i nieśmiertelna”, dzięki której transcenduje on wszystko, co żyje na tym świecie, i jako stworzony na obraz Boży, kieruje się ku swojemu Pierwowzorowi - Bogu wiecznemu. Zdaniem S. Swieżawskiego powyższe ujęcie natury człowieka świadczy o tym, że antropologia soborowa oparta na przesłankach biblijnych, została zinterpretowana w duchu tomistycznym ${ }^{8}$. Człowiek nie byłby podmiotem, gdyby był tylko ciałem, wiązką cielesnych popędów i nieświadomych dynamizmów. Realistyczne spojrzenie na niego każe określić go raczej jako duszę działającą sprawczo w ciele i poprzez ciało, i wchodzącą w kontakt ze światem zewnętrznym. Jego podmioto-

${ }^{8}$ S. Swieżawski, Vaticanum II a problemy kultury współczesnej, w: J. Homerski i F. Szulc (red.), W dwudziestolecie Soboru Watykańskiego II. Recepcja - doświadczenia-perspektywy, Lublin 1987, s. 61. 
wość jako bytu cielesno-duchowego nie ogranicza się jednak do płaszczyzny socjologicznej, lecz zawiera w sobie otwarcie się ku Bogu: człowiek ,jest zdolny do poznania i miłowania swego Stwórcy" (KDK 12), do nawiązania relacji z Bytem najwyższym stojącym u podstaw stworzenia, z Bogiem objawiającym się jako Osoba, Podmiot par excellence. Ojcowie Soborowi chcą powiedzieć, że wielka godność, wielkość człowieka - a więc i jego podmiotowość - polega obok podobieństwa do Boga także na „partnerstwie” z Osobowym Bogiem we wzajemnym poznaniu i miłości ${ }^{9}$. Bóg jest Partnerem o najwyższej wartości i godności.

Godność człowieka, według wykładni soborowej, uwidocznia się następnie w takich bardziej szczegółowych elementach obrazu Bożego, jak rozumność i wolność, sumienie i postawa wobec tajemnicy śmierci, a następnie w powierzonym mu przez Boga pierwotnym powołaniu. „Człowiek słusznie sądzi, że uczestnicząc w świetle Bożej myśli góruje swym rozumem nad światem rzeczy" (KDK 15). Pierwszym elementem obrazu Bożego w człowieku jest jego rozum, zdolność myślenia. Owa szczególna władza, dzięki której człowiek dokonał tak wielkiego postępu w sensie naukowo-technicznym, zostaje objaśniona we wspomnianej Konstytucji jako uczestnictwo w ,świetle Bożej myśli”. Przejawem tego jest zwłaszcza każdorazowe „,szukanie [przez człowieka] prawdy głębszej” i „odnajdywanie jej”, czyli dochodzenie do pewnej mądrości - najgłębszej prawdy o rzeczywistości ludzkiej. Dzięki niej człowiek może przekroczyć horyzont rzeczy widzialnych i uzyskać wgląd w sprawy niewidzialne. Z tej racji podmiotowość człowieka doznaje pewnego uwznioślenia w stosunku do tej, jaka się ujawnia jedynie w płaszczyźnie immanentnej.

„Wolność prawdziwa [...] to szczególny znak obrazu Bożego w człowieku. Bóg bowiem zechciał pozostawić człowieka w ręku rady jego (Ekl 15, 14), żeby Stworzyciela swego szukał z własnej ochoty i Jego się trzymając, dobrowolnie dochodził do pełnej i błogosławionej doskonałości” (KDK 17). Wzmianka o wolności jako „szczególnym znaku obrazu Bożego” sugeruje, że jest ona jednym z najwspanialszych darów, jaki człowiek otrzymał od Boga i że jej aktualizacja i spełnienie się w niej wymaga od niego szukania Boga jako Dobra Najwyższego i „działania ze świadomego i wolnego wyboru, to znaczy osobowo, [jako] od wewnątrz poruszony i naprowadzony, a nie pod wpływem ślepego popędu wewnętrznego lub też zgoła przymusu zewnętrznego" (KDK 17). Bycie poruszonym i naprowadzonym od wewnątrz, np. przez Ducha Świętego, nie pomniejsza doskonałości podmiotu ludzkiego, lecz wskazuje na jego głębię duchową, zdolność przyzwolenia na wezwanie Boże i pójście za nim, ujawnia więc większą doskonałość ludzkiego podmiotu. Takiej zdolności nie posiada ktoś działający pod wpływem popędu czy przymusu, gdyż przestaje stanowić o sobie, być podmiotem w sensie bycia wolnym sprawcą swych aktów, swego działania.

${ }^{9}$ B. Inlender, Elementy personalizmu chrześcijańskiego w teologii grzechu, „Communio” 5 (1984), s. 18. 
Fakt, iż człowiek może być w głębi swej duszy poruszony i naprowadzony na dobro przez Ducha Bożego, łączy się ściśle z sumieniem, „,najtajniejszym ośrodkiem i sanktuarium człowieka, gdzie przebywa on sam z Bogiem, którego głos w jego wnętrzu rozbrzmiewa” (KDK 16). Ów „ośrodek i sanktuarium człowieka" to jakby najgłębsza warstwa obrazu Bożego w nim, ta mianowicie, w której może on usłyszeć głos Boży, Boski imperatyw: „czyń to, tamtego unikaj”. Prawe sumienie ciagle formowane przez Słowo objawione i wskazania Kościoła chroni człowieka przed tym, by nie poddał się ,„ślepej samowoli”, ale mądrze wybierał dobro i je urzeczywistniał. Można powiedzieć, że chroni ono człowieka w jego podmiotowości w płaszczyźnie moralnej.

Za kolejną oznakę obrazu Bożego w człowieku Konstytucja uznaje postawę człowieka wobec śmierci, postawę nacechowana, „lękiem przed [ewentualnym] unicestwieniem”. Posiadając duszę nieśmiertelną, człowiek ,instynktem swego serca słusznie osądza sprawę, jeśli wzdraga się przed całkowitą zagładą i ostatecznym końcem swej osoby i myśl o tym odrzuca" (KDK 18). Chodzi tu o lęk metafizyczny odzywający się w człowieku, którego nie jest on sam w stanie usunać, bo na przykład osiagnięcia medycyny mogą jedynie przedłużyć o ileś lat życie ludzkie, ale nie mogą uczynić go nieskończonym. Może go uśmierzyć jedynie wiara $\mathrm{w}$ to, że ,człowiek jest stworzony przez Boga dla szczęśliwego celu poza granicą niedoli ziemskiej” (KDK 18) i ona też stanowi gwarancję metafizycznej trwałości ludzkiego podmiotu.

Jeszcze innym przejawem godności i podmiotowości człowieka jest powierzone mu powołanie, które winien urzeczywistniać w trzech płaszczyznach: w odniesieniu do bytów niższych od siebie, w relacji do innych osób oraz w relacji do Boga Stwórcy i Zbawcy ${ }^{10}$. Jan Paweł II łączy je z całą strukturą człowieka stworzonego na obraz i podobieństwo Boże ${ }^{11}$. $Z$ tej racji należy je uznać za powolanie pierwotne, odmienne od tego otrzymywanego od Boga w Chrystusie przez odkupieńczą miłość i łaskę.

$\mathrm{Na}$ czym polega owo powołanie człowieka względem bytów niższych? „Bądźcie płodni i rozmnażajcie się - powiedział Bóg do pierwszych rodziców - abyście zaludnili ziemię i uczynili ją sobie poddaną; abyście panowali nad rybami morskimi, nad ptactwem powietrznym i nad wszystkimi zwierzętami pełzającymi po ziemi" $(\mathrm{Rdz} 1,28)$. Jako rozumny i wolny podmiot, człowiek z woli Stwórcy ma władzę panowania nad bytami niższymi, „aby rządził i posługiwał się nimi dając chwałę Bogu" (Ek1 7, 3-10) (KDK 12). Może on zapanować nad

${ }^{10}$ Por. E. Schillebeeckx, Fede cristiana ed aspettative terrene, w: E. Giammancher (red.), La Chiesa nel mondo contemporaneo. Commento alla costituzione pastorale „Gaudium et spes”, Roma 1967, s. 107.

${ }^{11}$ „W mocy właśnie tego «obrazu» człowiek jako podmiot poznania i wolności nie tylko jest wezwany do przeobrażania świata wedle miary swoich słusznych potrzeb, nie tylko jest powołany do małżeńskiej wspólnoty osób (communio personarum), która daje początek rodzinie, a pośrednio wszelkiemu społeczeństwu, ale jest wezwany do Przymierza z Bogiem". Jan Paweł II, Wierze w Boga Ojca Stworzyciela, Vaticana 1987, s. 272. 
ziemią leżącą odłogiem, uprawiać na niej różne rośliny, może polować na zwierzęta i je hodować, może trudnić się rybołówstwem itp. Te cecha obrazu Bożego w człowieku jest konsekwencją jego duchowości i podkreśla jego podmiotowość w stosunku do świata zwierząt, roślin i materii nieożywionej. Winno to być niewątpliwie panowanie mądre nie degradujące świata, lecz chroniące go dla przyszłych pokoleń.

Obraz Boży w człowieku pozostałby niekompletny, gdyby był widziany jedynie w aspekcie indywidualnym. Bóg nie stworzył człowieka ostatecznie samotnym, lecz istotą społeczną, „toteż bez stosunków z innymi nie może [on] ani żyć, ani rozwinąć swoich uzdolnień" (KDK 12; por także nr 32). W naturę moralną i duchową człowieka Stwórca wpisał prawa życia społecznego, z których najważniejsze to miłość Boga i bliźniego (KDK 23), szacunek dla innych (ze względu na to, że wszyscy, posiadając duszę rozumną i będąc stworzeni na obraz Boga, są równi, że cieszą się tym samym powołaniem i przeznaczeniem [KDK 29]), a także sprawiedliwość względem innych, odpowiedzialność za nich i solidarność z innymi. Warte zaakcentowania jest to, że „osoba ludzka jest i powinna być zasada, podmiotem i celem wszystkich urządzeń społecznych, ponieważ z natury swej koniecznie potrzebuje życia społecznego" (KDK 25). Ostateczny cel jej życia, jak wykazano, jest ponad społeczeństwem, dla tego też ona je przekracza, transcenduje i to właśnie społeczeństwo winno wspierać osobowy i podmiotowy rozwój człowieka, choć on ze swej strony powinien także wypełniać względem niego wszystkie swoje zobowiązania.

Bóg stworzył człowieka „mężczyzną i niewiastą” (Rdz 1, 27). Prototypem społeczności ludzkiej jest małżeństwo i rodzina. Mężczyźnie i kobiecie łączącym się w małżeństwo Stwórca powierzył powołanie do przekazywani życia nowym pokoleniom ludzi: „Bądźcie płodni i rozmnażajcie się...” (Rdz 1, 28). Małżeństwo ustanowione przez Boga ma być „miejscem” przekazywania życia i odzwierciedlając sobą miłość Boga winno tworzyć właściwe środowisko rozwoju dla poczętego dziecka, by w nim kształtowała się zdrowa osobowość i właściwe postawy wobec innych, Boga i świata, by kształtowała się w nim podmiotowość relacyjna.

„Osobliwą rację godności ludzkiej stanowi powołanie człowieka do uczestnictwa w życiu Boga" (KDK 19). To uczestnictwo otrzymuje człowiek od początku, gdyż zostaje obdarowany pierwotną niewinnością, sprawiedliwością, miłością i łaską. Jan Paweł II mówi o pierwszym przymierzu ,zawartym jakby przed progiem ziemskiej historii człowieka"12, mając na myśli, jak się wydaje, to obdarowanie łaską uczestnictwa w życiu Boga na samym początku, w raju, i powołanie do niego. Potem to uczestnictwo było określane przez kolejne przymierza, a więc to zawarte z Noem (Rdz 9), z Abrahamem (Rdz 15 i 17), z ludem izraelskim na Synaju (Wj 19) - mające wyjątkowe znaczenie w historii relacji

12 Jan Paweł II, Mężczyznq i niewiasta stworzyt ich. Chrystus odwohuje się do „poczqtku”, t. I, Lublin 1981, s. 67. 
Izraela z Bogiem, przymierze z Dawidem (2 Sm 7) i tzw. przymierze kapłańskie (Lb 18, 19). Najdoskonalszym Przymierzem będzie Nowe, zawarte pomiędzy Bogiem i ludźmi w Chrystusie, w Jego krwi (w nawiązaniu do krwi ofiarniczej w dawnym Przymierzu - Wj 24, 8) przelanej dla usprawiedliwienia grzesznego człowieka, przynoszące pełniejszy udział w życiu Boga.

Biorąc pod uwage to, że przymierze Izraela z Bogiem, a tym bardziej to dokonane w Chrystusie, jest rodzajem umowy pochodzącej od Boga, w której dwie strony zobowiązują się w nim do przestrzegania pewnych warunków, że człowiek zobowiązuje się do wierności Bogu, jeśli chce cieszyć się Jego błogosławieństwem i łaską - tenże człowiek uznany jest przez Boga za partnera, za podmiot, za osobę, z którą On pragnie rozmawiać (KDK 19) i wychowywać ją do coraz pełniejszej wolności, wolności synów Bożych. Uznany jest przez Boga Trójjedynego w swym życiu wspólnotowym, małżeńskim, rodzinnym, plemiennym, narodowym i jako rodzina ludzka. Winien przeto również uznawać Go za Ojca i odnosić się do innych ludzi w duchu braterskim. „Wszyscy bowiem, stworzeni na obraz Boży (...) powołani są do jednego i tego samego celu, to jest do Boga samego" (KDK 24).

\section{Godność i podmiotowość ludzka pomniejszona przez grzech i odzyskana, i zadana w Chrystusie}

Wielka godność człowieka i jego podmiotowość ujawniają się nawet w sytuacji grzechu, kiedy to człowiek dobrowolnie decyduje się powiedzieć Bogu - „nie”. Księga Rodzaju podaje, że człowiek przebywający w raju otrzymał od Boga polecenie: „Z wszelkiego drzewa tego ogrodu możesz spożywać według upodobania; ale z drzewa poznania dobra i zła nie wolno ci jeść, bo gdy z niego spożyjesz, niechybnie umrzesz" (2, 16-17). Bóg występuje tu w roli Prawodawcy i dzieląc się z człowiekiem dobrami duchowymi (sprawiedliwość pierwotna, miłość) i materialnymi (ziemia, rośliny i zwierzęta) oczekuje od niego, by wybierał dobro i życie a nie zło i śmierć. Traktuje go jako swego partnera, jako podmiot zdolny do decydowania o swej przyszłości i odpowiedzialny za siebie i za swą przyjaźń z Nim.

Z dalszych stron Księgi Rodzaju dowiadujemy się, że człowiek nadużył swej wolności i nie wypełnił przykazania Bożego. Uwierzył sugestiom węża, iż ,,będzie jak Bóg znający dobro i zło" $(3,5)$ i dał się zwieść zmysłowym upodobaniom. W konsekwencji przestał ufać Bogu i postanowił sam decydować o tym, co jest dobre i co złe, przywłaszczając sobie prawo boskiego Prawodawcy. Tymczasem „dobro i zło” to rzeczywistość, którą tylko Bóg jest w stanie pojąć, przeniknąć i opanować ${ }^{13}$, dlatego Adam, a także każdy człowiek, powinien zaakceptować

13 J. Carreira das Neves, Zlo w Biblii, „Communio” 3 (1990), s. 4. 
swój status stworzenia i zależności od Boga i zdać się na Jego wszechwiedzę i przykazania.

Grzech pierwszego człowieka, partnera i przyjaciela Boga, polega więc na wewnętrznym akcie nieufności, nieposłuszeństwa wobec Stwórcy i na zewnętrznym akcie zerwania owocu z drzewa poznania dobra i zła, będącego symbolem wszechwiedzy przysługującej Bogu, ujawnia więc pełną negatywną sprawczość człowieka-podmiotu. Następstwa grzechu pierworodnego ujawniają się zarówno w samym człowieku, jak i w jego relacji do Boga, innych ludzi i świata natury, i z Adama przechodzą na jego potomstwo.

Ów grzech można uznać w pierwszym rzędzie za niegodziwość i błąd popełniony na własną niekorzyść za podpuszczeniem szatana, nieprzyjaciela natury ludzkiej. Nie odpowiada on bowiem prawdzie o człowieku jako bycie względnym, stworzeniu i jego najgłębszemu dążeniu do dobra, wszczepionemu mu przez Stwórcę. Św. Tomasz z Akwinu stwierdzi, że grzech pierworodny spowodował cztery rany w naturze ludzkiej: ranę niewiedzy (ignorantia), zaciemniając do pewnego stopnia rozum człowieka na prawdę; ranę przewrotności (malitia), osłabiając wolę w dążeniu do dobra; ranę słabości (vulnus infirmitatis), naruszając właściwe ukierunkowanie siły gniewliwej wobec zła; i ranę pożądliwości (vulnus concupiscientiae), pozbawiając umiaru i kontroli pragnienie przyjemności. Owe cztery zranienia dotykają natury ludzkiej w czterech władzach człowieka, mogących być podmiotami czterech cnót kardynalnych: rozumie, w którym przebywa roztropność; woli, będącej siedzibą sprawiedliwości; władzy gniewliwej na której bazuje cnota męstwa; i we władzy pożądliwej, na której się opiera cnota umiarkowania ${ }^{14}$. Wymienione rany powodują dezintegrację sił natury (a nie samej natury jako takiej, rozumianej jako siedlisko wymienionych skłonności) wpierw scalonej wewnętrznie i poddanej rozumowi i woli Bożej. Efektem tego rozprzężenia jest to, że człowiek doznaje przeszkód w dążeniu do dobra i w jego realizacji, w nabywaniu sprawności dobrego działania, cnoty, w rozwoju duchowym ukierunkowanym na swe spełnienie w Bogu. Trzeba tu jeszcze dodać, że grzech pierworodny był jakąś siłą zniewalającą człowieka i że jakąś siłą pozostał on w swych skutkach, jako skłonność do złego nadal, skoro św. Paweł, opisując stan człowieka po tym grzechu, twierdzi, że „,nie czyni [on] dobra, którego chce, ale czyni to zło, którego nie chce”, że to zło [mu] ,się narzuca” i ,że podbija [go] w niewolę" (Rz 7, 18-23). Człowiek nie jest w stanie sam wyzwolić się z tej siły i potrzebuje Bożej pomocy, potrzebuje Zbawcy.

Jak zauważono, grzech ten zniszczył relację człowieka do Boga Prawodawcy i Przyjaciela, w którego życiu człowiek miał pierwotnie udział. Odwracając się od Boga przez przewrotny wybór, Adam zwrócił się ku sobie samemu, niejako zamknął się w sobie i w rzeczach stworzonych. Skierował się w przeciwnym kierunku niż ten prowadzący ku Dobru najwyższemu, wpisany w jego naturę kierunek spełnienia się w swym człowieczeństwie i podmiotowości, uważając, że

${ }^{14}$ STh, q. 85 , art. 3. 
czy to sam, czy jako społeczność pokieruje swym życiem. Popadł jednak w grzechy, w pychę, o czym świadczy na przykład budowa wieży Babel (Rdz 11, 1-9).

Grzech pierworodny wpłynął również na zniekształcenie relacji człowieka do innych, na zniszczenie przyjaźni międzyludzkiej, o czym świadczy na przykład oskarżenie Ewy przezAdama wobec Boga: „Niewiasta, którą postawiłeś przy mnie, dała mi owoc z tego drzewa i zjadłem" (Rdz 3, 12), a jeszcze bardziej zazdrość, wrogość Kaina wobec Abla i odebranie mu życia (4, 1-16). Wraz z tym grzechem relacja więc człowieka-podmiotu do innych podmiotów popada w dysharmonię.

Kolejnym skutkiem grzechu pierworodnego jest zniszczenie harmonii ze światem natury. Wpierw Adam nadał nazwę wszystkim stworzeniom, czyli potrafił z łatwością zapanować nad nimi (Rdz 2, 20), po grzechu ujawnia się dysharmonia pomiędzy nim a przyroda, łatwo poddana ziemia staje się przeklęta, ujawnia się pewien opór materii, z którym człowiek będzie się musiał zmagać $\mathrm{w}$ pocie czoła $(\operatorname{Rdz} 3,17)$, by ją poddać sobie i zapewnić sobie i najbliższym konieczne dobra materialne. Będzie musiał wyrywać ziemi pożywienie i jako „proch” powrócić do niej. Także więc działanie człowieka-podmiotu zostanie naznaczone trudem zmagania się ze swym losem.

Bóg, pozbawiając człowieka po grzechu pierworodnym wcześniejszego uprzywilejowanego stanu, nie przestał jednak opiekować się nim i prowadzić go indywidu-alnie i jako lud, naród wybrany, do wyzwolenia z tego stanu, co dokona się „W pełni czasów” w Jezusie Chrystusie. W Nim jako w Słowie Wcielonym, Bogu-Człowieku, odsłania się zarazem nowa, pełniejsza perspektywa dla człowieka i jego spełnienia się. Dają temu wyraz Ojcowie Soboru w cytowanej Konstytucji, gdy stwierdzają: „Tajemnica człowieka wyjaśnia się naprawdę dopiero w tajemnicy Słowa Wcielonego [...] Chrystus, nowy Adam już w samym objawieniu tajemnicy Ojca i Jego miłości objawia w pełni człowieka samemu człowiekowi i okazuje mu najwyższe jego powołanie" (KDK 22). To, że antropologia soborowa kulminuje w chrystologii, zostało zapowiedziane już w wykładzie wprowadzającym do Konstytucji duszpasterskiej o Kościele w świecie współczesnym Gaudium et Spes, gdy stwierdzono tam, iż Chrystus jako Pan i Nauczyciel jest, ,kluczem, ośrodkiem i celem całej ludzkiej historii", i że w świetle Chrystusa Sobór zamierza wyjaśnić tajemnicę człowieka oraz współdziałać z ludzkością w rozwiązaniu głównych problemów naszego czasu (KDK 10). Jan Paweł II, nawiązując do tej myśli, stwierdzi, że Chrystus przyniósł „klucz do zrozumienia tej wielkiej i podstawowej rzeczywistości, jakąjest człowiek. Człowieka bowiem - dopowie Papież - nie można do końca zrozumieć bez Chrystusa. A raczej - człowiek nie może siebie do końca zrozumieć bez Chrystusa. Nie może zrozumieć, ani kim jest, ani jaka jest jego właściwa godność, ani jakie jest jego powołanie i ostateczne przeznaczenie. Nie może tego wszystkiego zrozumieć bez Chrystusa" ${ }^{15}$. Dlaczego Chrystus jest „kluczem” do zrozumienia prawdy o tym, kim jest człowiek, jaka jest jego godność, powołanie i przeznaczenie?

${ }^{15}$ Jan Paweł II, Homilia podczas Mszy św. na Placu Zwycięstwa, Warszawa - 2 VI 1979, w: Jan Paweł II, Przemówienia i homilie. Polska 2 VI-10 VI 1979, Kraków 1979, s. 30. 
Jeśli w zrozumieniu prawdy o tym, kim jest człowiek, ważna jest jego wielka godność, podmiotowość, którą objaśniono na początku w świetle teologii stworzenia, oraz jego relacja do Boga ,na początku”, to te dwa aspekty człowieczeństwa jaśnieją jeszcze wyraźniej w Chrystusie niż w jakimkolwiek innym człowieku, gdyż On jest i ,«obrazem Boga niewidzialnego» (Kol 1, 15) i człowiekiem doskonałym" (KDK 22). Będąc człowiekiem doskonałym, jest wolny od wszelkiego grzechu i skłonności do niego, nie jest dotknięty żadną z wymienionych czterech ran pochodzących z grzechu pierworodnego, ma więc jasną i niezniekształconą świadomość tego, kim jest człowiek w sobie i w relacji do Boga, innych i świata oraz niczym niezakłócone ukierunkowanie na dobro. Dlatego Ojcowie Soborowi moga powiedzieć o Chrystusie, że „objawia [...] człowieka samemu człowiekowi”. Objawia go „w pełni”, ponieważ w Nim, Synu Bożym, który „,przez wcielenie swoje zjednoczył się jakoś z każdym człowiekiem", przybrana natura ludzka „została wyniesiona do wysokiej godności” (KDK 22). Uzyskała w Nim jeszcze wyższą godność niż u Adama w stanie pierwotnej sprawiedliwości i świętości.

Chrystus ukazuje każdemu człowiekowi, że jego powołaniem i przeznaczeniem jest uczestnictwo w życiu Bożym i przez odkupienie, którego dokonał na krzyżu, otworzył drogę do niego: „Jako niewinny Baranek krwią swoją dobrowolnie wylaną wysłużył nam życie i w Nim Bóg pojednał nas ze sobą i między nami samymi oraz wyrwał z niewoli szatana i grzechu” (KDK 22). Rozważając tajemnicę odkupienia, ową, jak ją określił Jan Paweł II, „wstrząsającą tajemnicę miłości” (RH 9) Boga, człowiek może zrozumieć, iż Bóg jest miłością (1 J 4, 8. 16), a nie przeciwnikiem człowieka, jak to wmawiał Adamowi szatan, ojciec kłamstwa (J 8, 44). Może przybliżyć się do Chrystusa z poczuciem swojej godności i nędzy i zasymilować tę tajemnicę, i zdumieć się nad sobą samym, nad swoją wartością w „oczach” Stwórcy i Zbawiciela, i uwielbić Boga w najgłębszej pokorze, tj. prawdzie o sobie przed Bogiem (RH 10). Wtedy odkryje szczyt swej podmiotowości, czując się umiłowany przez Boga, odkupiony przez Chrystusa i przeznaczony do wspólnoty z Nim i z Ojcem, i z Duchem Świętym.

Czy jednak tenże człowiek może dojść do wyznaczonego mu przez Boga i odsłoniętego przez Zbawiciela celu? Człowiek, który przez chrzest św. zostaje uwolniony od grzechu Adama, a który jako jego ,potomek” nosi w dalszym ciagu w sobie rany grzechu, zarzewie grzechu? Czy nie podda się jego sile, skłonności i nie wkroczy na drogę grzechu?

Konstytucja duszpasterska o Kościele nie tylko nakreśla zarys antropologii i wzniosłe powołanie człowieka, ale także ukazuje głęboką nędzę, której konkretny człowiek doświadcza we współczesnym świecie. Wymienia wiele jej przejawów, takich jak np.: brak równowagi pomiędzy nowoczesnym rozumem praktycznym a rozumowaniem teoretycznym, nowe rodzaje niewoli społecznej i psychicznej, rozbieżności natury politycznej, gospodarczej, rasowej i ideologicznej; niebezpieczeństwo wojny mogącej się skończyć wielką zagładą ludzkości (KDK 4. 10). Powracamy tu do postawionego we wstępie pytania: czy wielkie osiągnięcia ludzkości idą w parze z jej postępem etycznym i duchowym, czy 
też ów postęp nie zostaje spożytkowany w służbie człowieczeństwa, umacniania podmiotowości człowieka? Powodem tych rozdźwięków w społeczeństwie jest nieuleczone rozdarcie w samym człowieku, wspomniane rany ignorancji, przewrotności, słabości i pożądliwości w jego naturze, jego słabość i grzeszność. Czy współczesny człowiek jest ich świadom, czy też nie? Dlaczego lekceważy on grzech i skłonności do niego, postrzegając naturę ludzką zbyt optymistycznie? Nie uświadamiając sobie swojej realnej kondycji nie jest w stanie przezwyciężyć swojej nędzy! Tymczasem grzech mieszkający w jego sercu $(\mathrm{Rz} 7,17)$ rodzi grzech kolektywny, wytwarzając atmosferę grzechu stającą się niejako prawem społecznym i zniewalającą wielu ${ }^{16}$.

Według św. Tomasza, każdy inny grzech uczynkowy może powiększać rany grzechu pierworodnego w człowieku i może się to dokonywać niemal w nieskończoność, jeśli człowiek nie oprze się jego sile ${ }^{17}$. Konieczne jest, jak sugeruje S. Sawicki, mówienie o ,antropologii niedojrzałości”, czyli antropologii ukazującej słabość, skażenie i grzech człowieka, jako dopełnienie antropologii jego godności, ,jako kontrprawdę o człowieku współczesnym, urzeczonym, zafascynowanym i ograniczonym... samym sobą". Taka antropologia może się stać „wielkim przygotowaniem na jego spotkanie z Chrystusem, Chrystusem prawdziwej nadziei"18. Taka antropologia powinna zarazem ukazywać człowieka-podmiot jako zadanie i wskazywać sposób jego urzeczywistnienia się.

Winna ona ukazywać najpierw rolę Ducha Świętego w dążeniu człowieka do zjednoczenia z Bogiem w modlitwie i realizacji nowego prawa miłości (KDK 22). Duch Święty, któremu chrześcijanin winien być poddany w modlitwie, by mógł odkryć wolę Bożą i ją wypełnić, nie pozbawia go jego podmiotowości, ale respektuje jego wolność i przyzwolenie. Nawet gdy dzięki darom Ducha Świętego pozwala się poruszyć Duchowi Bożemu i w tym znaczeniu okaże się „,bierny”, to dalej pozostaje sprawcą udzielonego Bogu przyzwolenia. Pozostanie podmiotem łaski uświęcającej otrzymanej od Boga, z którą winien współpracować w swych aktach wewnętrznych i uczynkach.

Umocniony Duchem Świętym jest w stanie naśladować Jezusa Chrystusa w życiu dla innych. „Włączony w orbitę Boskiego Bytu” może urzeczywistniać się zarówno w zakresie indywidualnym, jak i wspólnotowym na sposób właściwy dla osoby ${ }^{19}$, stając się darem dla innych. „Człowiek [bowiem] będąc na ziemi jedynym stworzeniem, którego Bóg chciał dla niego samego, nie może odnaleźć się w pełni inaczej jak tylko poprzez bezinteresowny dar z siebie dla innych" (KDK 24).

${ }^{16}$ P. Góralczyk, Społeczny wymiar grzechu, „Communio” 5 (1984), s. 39.

${ }^{17} \mathrm{Za}$ : L. Balter, Problem reinterpretacji skutków grzechu pierworodnego, w: tenże i inni (red.), Zło wświecie, Kolekcja „Communio” 7, Poznań 1992, s. 289.

${ }^{18}$ S. Sawicki, Chrześcijaństwo a kultura, w: J. Homerski i F. Szulc (red.), dz. cyt., s. 73-74.

${ }^{19}$ W. Słomka, Podmiotowy charakter osoby - godność człowieka, w: T. Bielski (red.), Być człowiekiem, Poznań-Warszawa 1974, s. 89. 


\section{The man as the subject in the theological perspective} (Summary)

The Author shows the meaning of the Word of the Subject and is interesting on the religious and theological sense of this category. The paper goes out from the multiple meaning of the Word of the subject an concentrate the attention on the religious and theological meaning. Standing on the position of the theological anthropology, that will be resuming especially in the Pastoral Constitution of the Church in the contemporary World the Author built his opinion also on the basis of the elements of the theology of the creation, theology of the Imago Dei is showing the fundaments of the human dignity and the subjectivity of the man. The dignity and subjectivity of the man reveals also in the situation of the sin. The result of the original sin and each $\sin$ in general (the deeds $\sin$ ) is the minor dignity and yield the disintegrated subjectivity, caused from disharmony of the relation between the Man and God, and between the Man and the others and the World of the nature. In Christ, God and Man the human dignity is saved and particularly exalted. The realization of this last is conditioned from the openness for the acting of the Power of the Holy Spirit in us, and from the spiritual Work and Collaboration with the God in prayer and in working, in realization of the Commandments of the Law of God and the Neighbors and on doing the Donation from his own self for the others. 